\title{
Conditioned medium increases the polyploid cell composition of bovine somatic cell nuclear-transferred blastocysts
}

\author{
G-P Li, K L White, K I Aston, L N Meerdo and T D Bunch \\ Department of Animal, Dairy and Veterinary Sciences, Utah State University, Logan, Utah 84322, USA \\ Correspondence should be addressed to T D Bunch; Email: tombunch@cc.usu.edu
}

\begin{abstract}
The effects of bovine cumulus cell-conditioned medium on cloned bovine embryonic development and subsequent chromosome complement were examined using an air-dry procedure. Conditioned media were prepared using CR1aa supplemented with either fetal bovine serum (FBS) or bovine serum albumin (BSA). Nuclear-transferred embryos were reconstructed with nuclei from cumulus cells. Similar cleavage, morula, and blastocyst development was observed in conditioned media groups compared with the co-culture group. No differences $(P>0.05)$ were observed in the composition of blastocyst chromosomes after co-culture in different media, either with or without starvation of donor cells. The overall diploid blastocyst rate ranged from $75 \%$ to $84 \%$. Chromosomal complement of blastocysts, however, was very different between conditioned medium and co-culture treatments. Overall incidence of chromosomal anomalies was $40 \%$ in conditioned medium, which was significantly higher $(P<0.001)$ than the co-culture group $(20 \%)$. Moreover, a higher incidence $(P<0.05)$ of chromosomally abnormal blastocysts $(\mathbf{4 1 . 5 \% )}$ ) was observed after culture with FBS-containing conditioned medium than those cultured in BSA-containing conditioned medium (31.4\%). No diploid improvement was observed after exchange of the culture system from conditioned medium to co-culture, or from co-culture to conditioned medium after the first $72 \mathrm{~h}$ of culture. The results of this study also indicated that the overall cell number was much lower $(P<0.01)$ in blastocysts with chromosomal abnormalities than those with a normal diploid state. We have concluded that medium conditioned with bovine cumulus cells increases the incidence of chromosomal anomalies in nuclear reconstructed embryos.
\end{abstract}

Reproduction (2004) 127 221-228

\section{Introduction}

Successful somatic cell nuclear transfer (NT) has now been achieved in several mammalian species as reported by the birth of offspring. The overall efficiency of the technique, however, remains low. In each animal species so far studied, less than $10 \%$ of transferred embryos typically survive to term (Hill 2002). A high frequency of early post-implantation developmental arrest and abortion exists, especially in cattle. Studies in cattle and sheep have shown the most significant period for fetal loss to be at the time of placental attachment, which occurs between the first and second month of gestation (Hill 2002). The exact mechanism(s) of these phenomena is still unclear. The NT procedures, i.e. removal of oocyte nuclear material, transfer of a differentiated cell into an enucleated cytoplast, fusion with electric pulse, chemical or electric pulse activation, and culture conditions, can all lead to potential cell cycle blockages. All of these artificial manipulations can potentially influence the chromosomal composition of the resulting embryos. Approximately half of all human spontaneous abortions in the first and second trimesters are chromosomally abnormal (Burgoyne et al. 1991). Only a few reports have been published on the chromosome analysis of bovine NT embryos (Mohamed \& Takahashi 2000, Arat et al. 2002, Slimane-Bureau \& King 2002, Booth et al. 2003, Slimane-Bureau et al. 2003).

Although bovine embryos can be cultured in vitro in simple media under defined conditions (Keskintepe et al. 1995, Takahashi et al. 1996), the addition of growth factors facilitates embryo development (Paria \& Dey 1990, O'Neill 1997), which suggests that paracrine and/or autocrine pathways exist between helper cells and embryos. To mimic the in vivo environment, co-culture systems are widely used in the culture of in vivo or in vitro fertilized embryos (Van Langendoncket et al. 1996, Funston et al. 1997, Vanroose et al. 2001). Various studies have reported that co-culture improves the morphological development and implantation rate of exposed embryos. Numerous growth factors, receptors, and binding proteins are secreted into the medium by helper cells. Embryos have also been reported to secrete substances into their 
surrounding environment (Van Langendoncket et al. 1996, Izquierdo et al. 1999). Cell-free conditioned medium (CM) has been used in several laboratories in the culture of in vivo and in vitro fertilized embryos (Baranao et al. 1997, Funston et al. 1997, Ishiwata et al. 2000, Galli et al. 2003). Studies have shown that CM has similar effects on embryo development to those produced in various co-culture systems. It is thought that the CM system may eliminate partially, or completely, some of the in vitro culture artifacts, e.g. developmental blockage and fragmentation.

Currently, there are no reports on the chromosome complement of NT blastocysts derived from CM culture. This study was designed to determine: (1) the effects of medium conditioned by bovine cumulus cells on the subsequent development of NT bovine embryos and (2) the chromosome complements of NT blastocysts after CM culture.

\section{Materials and Methods}

Chemicals were purchased from Sigma Chemical Co. unless otherwise indicated.

\section{Oocyte maturation in vitro (IVM)}

Maturation of bovine oocytes was carried out according to routine procedures (Li et al. 2003). Briefly, bovine cumulus oocyte complexes (COCs) were aspirated from 3-8 mm diameter follicles from ovaries obtained from a local abattoir. Only COCs with a compact cumulus complex and a homogenous ooplasm were selected. The COCs were matured in TCM 199 with Earle's salts, L-glutamine and sodium bicarbonate (Gibco Inc., Grand Island, NY, USA) supplemented with $10 \%$ fetal bovine serum (FBS) (HyClone, Logan, UT, USA, $25 \mu \mathrm{g} / \mathrm{ml}$ gentamicin, $0.01 \mathrm{U} / \mathrm{ml}$ follicle-stimulating hormone (NIH-FSH-S17), $0.01 \mathrm{U} / \mathrm{ml}$ luteinizing hormone (USDA-bLH-6) and $1 \mu \mathrm{M}$ penicillamine, hypotaurine and epinephrine (PHE) in fourwell plates with $0.5 \mathrm{ml}$ medium and $30-50$ oocytes/per well under $39^{\circ} \mathrm{C}$ in humidified $5 \% \mathrm{CO}_{2}$ in air for $18-19 \mathrm{~h}$.

\section{Donor cell culture and preparation}

Bovine cumulus cells were used as nuclear donor cells. A primary cumulus cell line was established from six oocytes collected $18-20 \mathrm{~h}$ after the start of maturation. Cumulus cells were separated with $0.1 \%$ hyaluronidase (type-1), washed several times in Dulbecco's modified Eagles' medium (DMEM)/F12 (1:1) (Gibco Inc.), and cultured in DMEM/F12 supplemented with $10 \%$ FBS in $25 \mathrm{~cm}$ flasks at $37^{\circ} \mathrm{C}$ under $5 \% \mathrm{CO}_{2}$ in air. The cells were passed at $80 \%$ or more confluence. They were starved by culture in $0.5 \%$ FBS for 3-5 days. The non-starved cells were cultured in normal medium with $10 \%$ serum, and the $80 \%$ confluent cells were used as donors. Immediately before NT, cells were dissociated by trypsinization with $0.25 \%$ trypsin with EDTA solution (HyClone). Small sized $(10-12 \mu \mathrm{m})$ cells with a smooth round shape from both starved and non-starved groups were used as nuclear donor cells.

\section{Preparation of $\mathrm{CM}$}

CM was prepared from fresh CR1aa exposed to cumulus cell cultures for $24 \mathrm{~h}$. Twenty-four hours after passaging in DMEM/F12 + 10\% FBS (cells in one flask were seeded into four $25 \mathrm{~cm}^{2}$ flasks, once those cells reached $70 \%-80 \%$ confluence in $24 \mathrm{~h}$ ), the flasks were washed twice with CR1aa, and then $3 \mathrm{ml}$ fresh CR1 aa supplemented with $3 \%$ FBS (serum-containing CM; SCM) or $0.3 \%$ fatty acid free bovine serum albumin (BSA) (BSA-containing CM; BCM) was added. The SCM and BCM were collected $24 \mathrm{~h}$ after seeding and subsequently filtered $(0.2 \mu \mathrm{m})$ to remove cellular debris and stored at $4{ }^{\circ} \mathrm{C}$ for less than 2 weeks.

\section{Enucleation and NT}

After maturation, the cumulus cells were removed by vortexing COCs in TL-Hepes (Tyrode lactate Hepes buffered) medium containing $100 \mathrm{IU} / \mathrm{ml}$ hyaluronidase. Removal of chromosomes was carried out with the assistance of colcemid (Gibco) as described by Yin et al. (2002). Briefly, oocytes with first polar bodies were cultured into TCM 199 supplemented with $0.2 \mu \mathrm{g} / \mathrm{ml}$ colcemid for $2 \mathrm{~h}$. The eggs with membrane protrusions were transferred into TLHepes medium containing $7.5 \mu \mathrm{g} / \mathrm{ml}$ cytochalasin B and $0.1 \mu \mathrm{g} / \mathrm{ml}$ colcemid and then the protrusion and the first polar body were removed by a beveled pipette. Single cells were individually transferred to the perivitelline space of the recipient cytoplasts.

\section{Fusion and activation}

Fusion was performed using one direct current pulse of $1.2 \mathrm{kV} / \mathrm{cm}$ for $25 \mu \mathrm{s}$ by an Electro Cell Manipulator 2001 (BTX, San Diego, CA, USA) in $0.27 \mathrm{M}$ mannitol, $0.1 \mathrm{mM}$ $\mathrm{CaCl}_{2}, 0.1 \mathrm{mM} \mathrm{MgCl}$, and $0.05 \% \mathrm{BSA}$. Fused eggs were activated $24-25 \mathrm{~h}$ after the start of IVM with $5 \mu \mathrm{M}$ ionomycin for $5 \mathrm{~min}$, followed by treatment with $10 \mu \mathrm{g} / \mathrm{ml}$ cycloheximide in CR1aa plus $3 \% \mathrm{FBS}$ for $5 \mathrm{~h}$ at $38.5^{\circ} \mathrm{C}$ in $5 \% \mathrm{CO}_{2}$ in air.

\section{In vitro culture of NT embryos}

After activation, NT embryos were cultured in $30 \mu \mathrm{l}$ droplets of chemically defined medium (CDM) (Olson \& Seidel 2000, Li et al. 2003), or CR1 aa supplemented with $3 \% \mathrm{FBS}$ and co-cultured with monolayer bovine cumulus cells in experiment 1 , or cultured in SCM or BCM in experiments 2 and 3 overlaid with mineral oil at $39^{\circ} \mathrm{C}$ in $5 \% \mathrm{CO}_{2}$ in air for 7 days. Cleavage, morula and blastocyst stages were evaluated at $48 \mathrm{~h}$, day 5 and day 7 after activation (day 0 ) respectively.

\section{Chromosomal analysis and cell number count}

Day 7 blastocysts were prepared and examined for their cytogenetic composition and the number of nuclei contained within each embryo. Blastocysts were incubated in $0.05 \mu \mathrm{g} / \mathrm{ml}$ colcemid in culture medium for $5 \mathrm{~h}$. 
The blastocysts were then treated with $1 \%$ trisodium citrate for 10-15 min, and transferred individually onto a clean glass slide and fixed (Li et al. 1998, 2003). Slides were stained with $1 \%$ Giemsa for $10 \mathrm{~min}$. Chromosome spreads were examined at $1000 \times$ under oil, and the chromosome composition was determined for each blastocyst. Images were captured by digital camera with PIXERA Viewfinder Program (Pixera Corporation, Los Gatos, CA, USA) under a Zeiss microscope. The categories for the chromosome composition were classified as follows: diploid, polyploid (tetraploid), mixoploid (including $1 n / 2 n, 2 n / 3 n, 2 n / 4 n, 2 n / 3 n / 4 n)$, and aneuploid. Only those embryos with over four chromosome spreads were scored and analyzed. Embryos that did not show an interpretable metaphase spread because of gross overspreading or clumped chromosomes were not classified.

\section{Experimental design}

Three experiments were designed. Experiment 1 examined the effect of different media on blastocyst development of NT embryos and their chromosomal compositions. Fused NT embryos from starved or non-starved donor cells were randomly cultured in CDM or CR1 aa medium with coculture. On day 7 of culture, blastocysts were prepared for chromosomal analysis. Because no differences in blastocyst development and chromosomal composition between starved and non-starved donor cells were observed in experiment 1 , only non-starved cells were used in experiments 2 and 3.

Experiment 2 evaluated the effects of BCM and SCM on development and chromosomal composition of NT blastocysts. Fused NT embryos were randomly cultured in SCM and $\mathrm{BCM}$, and $\mathrm{CR} 1 \mathrm{aa}+3 \%$ FBS with co-culture as control.

Experiment 3: because of the effect of CM on blastocyst chromosomal composition in experiment 2, this experiment was designed to test whether changes of the culture system from co-culture to SCM or from SCM to co-culture after the first $72 \mathrm{~h}$ of culture would improve blastocyst diploid complements. Fused NT embryos were co-cultured in $\mathrm{CR} 1 \mathrm{aa}+3 \% \mathrm{FBS}$ for $72 \mathrm{~h}$, then transferred into fresh SCM for further culture (from co-culture to SCM; $\mathrm{CO}-$ SCM), or embryos were cultured in SCM for the first $72 \mathrm{~h}$, then transferred into the co-culture system up to day 7 (from SCM to co-culture; SCM-CO). Embryos that were cultured during the entire culture period in co-culture or in SCM for 7 days were used as the controls.

\section{Statistical analysis}

Differences in blastocyst cell numbers between groups were analyzed by one-way ANOVA. Differences in rates of blastocyst development and chromosome composition between experimental groups were analyzed using Student's $t$-test. A probability of $P<0.05$ was considered statistically significant.

\section{Results}

\section{Experiment 1}

A total of 349 fused oocytes was cultured in six replicates. As shown in Table 1, cleavage, morula and blastocyst rates were similar between starved and non-starved donor cells, or between CDM and CR1aa co-culture. Blastocyst development was approximately $30 \%$. Of the blastocysts produced, 75,84 , and $80.7 \%$ were diploid in the starved, non-starved in CDM, and non-starved in the CR1 aa coculture groups respectively (Table 2 ). The anomalies in the three groups ranged from 16 to $25 \%$. Mixoploids of $2 n / 3 n, 2 n / 4 n$, and $2 n / 3 n / 4 n$, and $4 n$ cells were observed among the anomalies.

\section{Experiment 2}

As shown in Table 3, 561 reconstructed embryos were randomly cultured in the SCM, BCM, and co-culture systems in seven replicates. Development to the blastocyst stage was similar $(P>0.05)$ in the SCM, BCM, and coculture groups. Hatching blastocysts were also similar

Table 1 Development of bovine NT embryos using starved and non-starved cumulus cells as donors and cultured in different media.

\begin{tabular}{llcccc}
\hline Co-culture in: & Donor cells & No. of embryos cultured & Cleavage $(\%)$ & Morula (\%) & Blastocyst $(\%)$ \\
\hline CDM & Starved & 158 & $127(80.4)$ & $59(37.3)$ & $44(27.8)$ \\
CDM & Non-starved & 100 & $85(85)$ & $37(37)$ & $30(30)$ \\
CR1aa & Non-starved & 91 & $78(85.7)$ & $36(39.6)$ & $26(28.6)$ \\
\hline
\end{tabular}

Table 2 Chromosomal composition of blastocysts from starved and non-starved donor cells and cultured in different media.

\begin{tabular}{|c|c|c|c|c|c|c|c|c|}
\hline \multirow[b]{2}{*}{ Co-culture in: } & \multirow[b]{2}{*}{ Donor cells } & \multirow{2}{*}{$\begin{array}{l}\text { No. of blastocysts } \\
\text { analyzed }\end{array}$} & \multicolumn{5}{|c|}{ Blastocysts containing $(\%)$ : } & \multirow{2}{*}{$\begin{array}{l}\text { Total with } \\
\text { anomalies }\end{array}$} \\
\hline & & & $2 n$ & $2 n / 3 n$ & $2 n / 4 n$ & $2 n / 3 n / 4 n$ & $4 n$ & \\
\hline CDM & Starved & 28 & $21(75)$ & $1(3.5)$ & $2(7.1)$ & 0 & $4(14.2)$ & 7 (25) \\
\hline CDM & Non-starved & 25 & $20(84)$ & $1(4)$ & $2(8)$ & $1(4)$ & $1(4)$ & $5(16)$ \\
\hline CR1aa & Non-starved & 26 & $21(81)$ & $1(3.8)$ & $2(7.6)$ & $1(3.8)$ & $1(3.8)$ & $5(19.3)$ \\
\hline
\end{tabular}


Table 3 Development of NT embryos cultured in SCM, BCM, and co-culture.

\begin{tabular}{lccccc}
\hline Culture & No. of embryos cultured & Cleavage $(\%)$ & Morula $(\%)$ & Blastocyst $(\%)$ & Hatching blastocysts $(\%$ of blastocysts) \\
\hline SCM & 209 & $174(83.3)$ & $67(32.1)$ & $50(23.9)$ & $27(54)$ \\
BCM & 184 & $149(81.0)$ & $76(41.3)$ & $45(24.4)$ & $26(57.8)$ \\
Co-culture & 168 & $137(81.5)$ & $65(38.6)$ & $50(30.0)$ & $33(66)$ \\
\hline
\end{tabular}

Table 4 Chromosomal composition of blastocysts derived from SCM, BCM, and co-culture.

\begin{tabular}{|c|c|c|c|c|c|c|c|c|c|c|}
\hline \multirow[b]{2}{*}{ Culture } & \multirow{2}{*}{$\begin{array}{l}\text { No. of blastocysts } \\
\text { analyzed }\end{array}$} & \multicolumn{6}{|c|}{ Blastocysts containing (\%): } & \multirow{2}{*}{$\begin{array}{l}\text { Total with } \\
\text { anomalies }\end{array}$} & \multicolumn{2}{|c|}{ Blastocyst cell no. $(n) *$} \\
\hline & & $2 n$ & $2 n / 3 n$ & $2 n / 4 n$ & $2 n / 3 n / 4 n$ & $4 n$ & Aneuploidy & & Diploids & Non-diploids \\
\hline SCM & 41 & $24(58.5)^{\mathrm{C}}$ & $2(4.9)$ & $7(17.0)$ & $2(4.9)$ & $4(9.7)^{\mathrm{a}}$ & $2(4.9)^{\mathrm{a}}$ & $17(41.5)^{\mathrm{a}}$ & $\begin{array}{c}83.3 \pm 20.1^{\mathrm{a}} \\
(24)\end{array}$ & $\begin{array}{c}59.2 \pm 18.7^{c} \\
(17)\end{array}$ \\
\hline $\mathrm{BCM}$ & 35 & $24(68.6)^{b}$ & $2(5.7)$ & $3(8.5)$ & $1(2.8)$ & $3(8.5)^{\mathrm{b}}$ & $2(5.7)^{\mathrm{a}}$ & $11(31.4)^{\mathrm{a}}$ & $\begin{array}{c}86.6 \pm 16.7^{\mathrm{a}} \\
(24)\end{array}$ & $\begin{array}{c}57.8 \pm 11.8^{\mathrm{c}} \\
(11)\end{array}$ \\
\hline Co-culture & 42 & $34(80.9)^{\mathrm{a}}$ & $1(2.4)$ & $4(9.5)$ & 0 & $1(2.4)^{\mathrm{b}}$ & $2(4.8)^{\mathrm{a}}$ & $8(19.1)^{b}$ & $99.8 \pm 19.1^{\mathrm{a}}$ & $\begin{array}{c}53.3 \pm 27.1^{\mathrm{c}} \\
(8)\end{array}$ \\
\hline
\end{tabular}

Values with different superscripts within each column except the 'Blastocyst cell no.' column are significantly different $(P<0.05) . *$ In the 'Blastocyst cell no.' column, values within each row: a,c $P<0.01$.

between the treatment groups. The chromosomal composition of blastocysts, however, was significantly different between the SCM, BCM, and co-culture groups. Only $58.5 \%$ of blastocysts from the SCM group were diploid, which was significantly lower than the BCM $(68.6 \%$, $P<0.05)$ and the co-culture groups $(80.9 \%, P<0.01$; Table 4). Aneuploid cells were also among the anomalies observed. Figure 1 shows the various categories of chromosomal composition in NT blastocysts. The cell number of blastocysts in the co-culture group was higher than that observed in CM groups, though the difference was not significant. Considerably fewer $(P<0.01)$ cells were observed in blastocysts with chromosomal anomalies than those with normal diploid compositions (Table 4).

\section{Experiment 3}

Based upon the findings in experiment 2 (that blastocysts derived from $\mathrm{CM}$ culture possessed more chromosome anomalies than co-culture), experiment 3 was designed to examine whether the diploid blastocyst rate could be improved by exchanging the culture system after the first $72 \mathrm{~h}$ of culture. No improvements were observed after exchanges from SCM to $\mathrm{CO}$ (SCM-CO) or from $\mathrm{CO}$ to SCM (CO-SCM). Blastocyst rates were similar $(P>0.05)$ among the four groups as shown in Table 5. Chromosomal anomalies in SCM-SCM, SCM-CO, and CO-SCM groups were $39.1,45.8$, and $31.8 \%$ respectively, which were significantly higher $(P<0.05)$ than that in the coculture group (Table 6). A $1 \mathrm{n} / 2 \mathrm{n}$ mixoploid blastocyst was found in the SCM-CO culture group, where seven identifiable haploid cells and four diploid cells were found out of 121 total cells (Fig. 1 shows the $1 \mathrm{n}$ ). The cell number in chromosomally abnormal blastocysts was significantly lower $(P<0.01)$ than in diploid blastocysts (Table 6).
Summarizing the results of experiments 1 through 3 , the diploid blastocyst rate was significantly higher $(P<0.001)$ in co-culture $(120 / 151,79.5 \%)$ than in CM (62/99, $62.6 \%$ ) (Table 7). There was no difference in the mitotic index (number of metaphase nuclei/total number of nuclei) between $\mathrm{CM}$ culture and co-culture embryos (11.8 \pm 5.6 and $12.1 \pm 4.7$ respectively).

\section{Discussion}

No reports have been published comparing methods of preparing $\mathrm{CM}$ with cumulus cells for use in culturing bovine NT embryos. Results in this study indicate that CM prepared with bovine cumulus cells, either serum-containing $\mathrm{CM}$, or BSA-containing $\mathrm{CM}$, yielded similar morula and blastocyst development compared with co-culture with bovine cumulus cells (Table 3). There have, however, been numerous studies reporting the incubation of in vitro produced (IVP) or in vivo embryos in medium conditioned with different cells (Kobayashi et al. 1992, 1997, Baranao et al. 1997, Liu et al. 1998, Joo et al. 2001). Cell numbers of blastocysts derived in CM were not different from coculture groups. Our data support the collective reports of others indicating that $\mathrm{CM}$ conditioned by different cells yields similar morula and blastocyst development to the co-culture system, whether the embryo is derived by in vivo, IVP, or NT procedures.

Results in this study showed that there were no differences in diploid blastocyst rates between CDM and CR1aa groups, or between starvation and non-starvation groups (Table 2). This suggests that culture medium and donor nuclear cell status do not affect chromosome composition at the blastocyst stage. This conclusion is in agreement with other studies where $82 \%$ (Mohamed \& Takahashi 2000) and $87 \%$ (Booth et al. 2003) of 

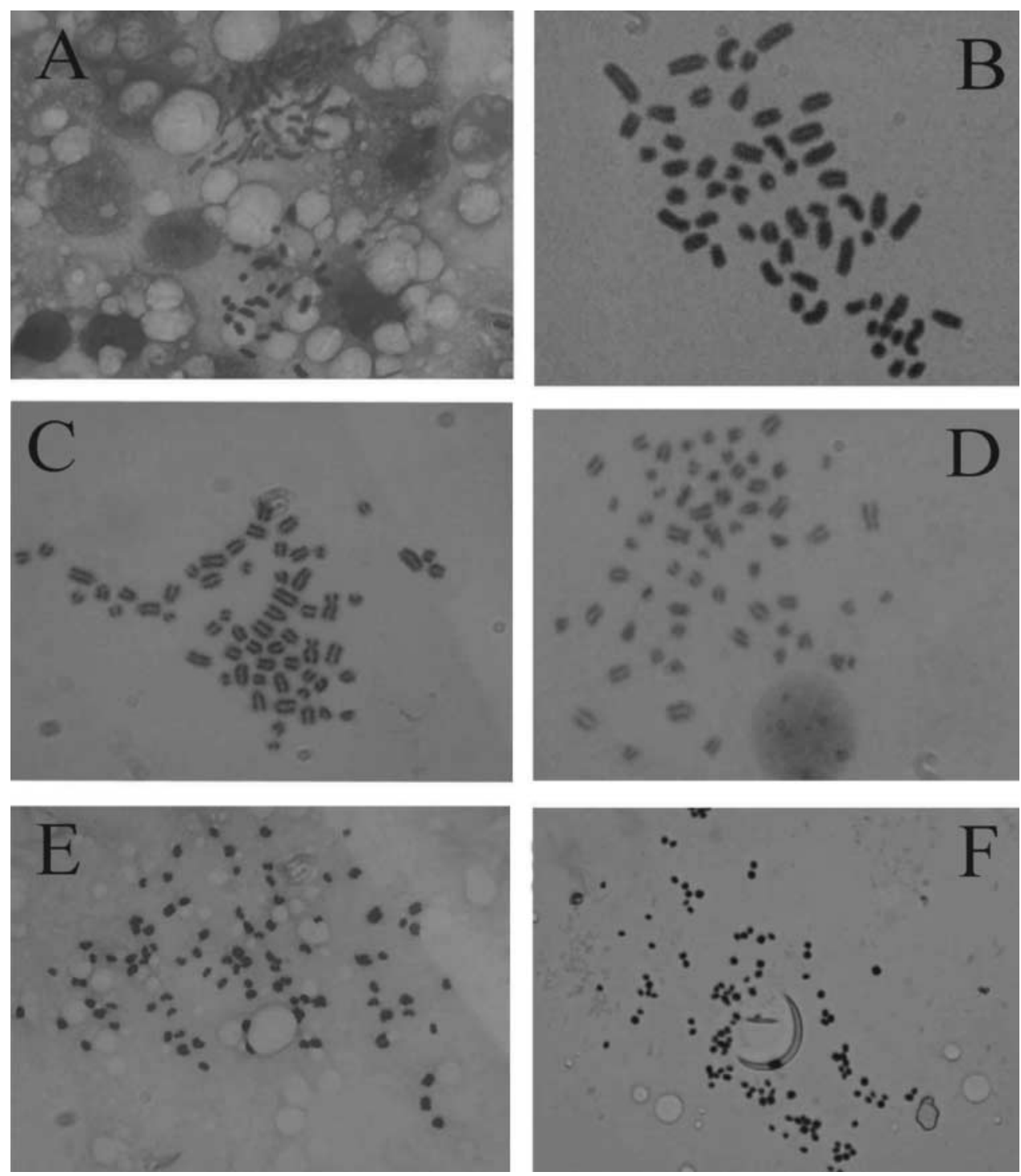

Figure 1 Chromosome spreads of haploid (A, two groups of haploid chromosomes), aneuploid (B, 56 chromosomes), diploid (C and D), triploid $(E)$, and tetraploid $(F)$. (A), (B), (C), (E), and (F) from CM culture and (D) from co-culture. $(B),(C)$, and (D) $1000 \times$ and $(A),(E)$, and $(F) 400 \times$.

NT blastocysts derived from cumulus cells, $78 \%$ from fetal fibroblasts and $88 \%$ from adult fibroblasts (Arat et al. 2002) were diploid. After culture with CM, however, a significantly higher incidence of chromosomal abnormalities was observed in SCM and BCM groups than in the co-culture group (Table 4). Normal chromosome complement rates did not improve, anomalies were still higher in SCM and changed groups than in co-culture alone in experiment 3 (Table 6). The results of this study suggest that factors leading to a higher incidence of chromosomal anomalies may be inherent within the CM.

Diploid chromosome rates of NT bovine blastocysts determined by karyotyping are approximately $80 \%$ (Mohamed \& Takahashi 2000, Arat et al. 2002, this study). Similar results were also reported by using fluorescent in situ hybridization protocols (Booth et al. 2003, SlimaneBureau et al. 2003). Mixoploids of 2n/3n, 2n/4n, and $2 n / 3 n / 4 n$, tetraploids, and aneuploids were observed in

Table 5 Blastocyst development of NT embryos after exchanges from SCM to CO or from CO to SCM $72 \mathrm{~h}$ later.

\begin{tabular}{|c|c|c|c|c|c|c|}
\hline 1st culture & 2nd culture & No. of embryos cultured & Cleavage $(\%)$ & Morula $(\%)$ & Blastocyst (\%) & Hatching blastocysts (\% of blastocysts) \\
\hline SCM & SCM & 115 & $97(84.3)$ & $32(27.8)$ & $23(20)$ & 9 (39) \\
\hline SCM & Co-culture & 114 & 97 (85) & $34(29.8)$ & $26(22.8)$ & 14 (53.8) \\
\hline Co-culture & SCM & 118 & 101 (85.6) & $29(24.5)$ & 22 (18.6) & 5 (22.7) \\
\hline Co-culture & Co-culture & 115 & 95 (82.6) & $41(35.7)$ & $32(27.8)$ & $15(46.9)$ \\
\hline
\end{tabular}


Table 6 Chromosomal composition of the blastocysts derived from the exchanged culture system.

\begin{tabular}{|c|c|c|c|c|c|c|c|c|c|c|}
\hline \multirow[b]{2}{*}{ Culture groups } & \multirow{2}{*}{$\begin{array}{l}\text { No. of blastocysts } \\
\text { analyzed }\end{array}$} & \multicolumn{6}{|c|}{ Blastocysts containing $(\%)$ : } & \multirow{2}{*}{$\begin{array}{l}\text { Total with } \\
\text { anomalies }\end{array}$} & \multicolumn{2}{|c|}{ Blastocyst cell no. $(n)^{*}$} \\
\hline & & $2 n$ & $1 \mathrm{n} / 2 \mathrm{n}$ & $2 n / 3 n$ & $2 n / 4 n$ & $2 n / 3 n / 4 n$ & $4 n$ & & Diploids & Non-diploids \\
\hline SCM-SCM & 23 & $14(60.9)^{b}$ & 0 & $2(8.7)$ & $4(17.4)$ & $1(4.3)$ & $2(8.7)$ & $9(39.1)^{\mathrm{a}}$ & $\begin{array}{c}82.2 \pm 19.5^{\mathrm{a}} \\
(14)\end{array}$ & $\begin{array}{c}72.1 \pm 19.3^{b} \\
(9)\end{array}$ \\
\hline $\mathrm{SCM}-\mathrm{CO}$ & 24 & $13(54.2)^{\mathrm{b}}$ & $1(4.2)$ & $2(8.3)$ & $7(29.1)$ & $1(4.2)$ & 0 & $11(45.8)^{\mathrm{a}}$ & $121.2 \pm 13.2^{\mathrm{a}}$ & $\begin{array}{c}61.5 \pm 21.0^{c} \\
(11)\end{array}$ \\
\hline $\mathrm{CO}-\mathrm{SCM}$ & 22 & $15(68.2)^{b}$ & 0 & $3(13.6)$ & $3(13.6)$ & 0 & $1(4.5)$ & $7(31.8)^{\mathrm{a}}$ & $\begin{array}{c}85.3 \pm 26.5^{\mathrm{a}} \\
(15)\end{array}$ & $\begin{array}{c}58.8 \pm 24.2^{\mathrm{c}} \\
(7)\end{array}$ \\
\hline $\mathrm{CO}-\mathrm{CO}$ & 30 & $24(80)^{\mathrm{a}}$ & 0 & $3(10)$ & $2(6.7)$ & 0 & $1(3.3)$ & $6(20)^{b}$ & $\begin{array}{c}96.2 \pm 20.1^{\mathrm{a}} \\
(24)\end{array}$ & $\begin{array}{c}57.1 \pm 15.6^{c} \\
(6)\end{array}$ \\
\hline
\end{tabular}

Values with different superscripts within each column except the 'Blastocyst cell no.' column are significantly different $(P<0.05) . *$ In the 'Blastocyst cell no.' column, values within each row: a,b $P<0.05$; a,c $P<0.01$.

Table 7 Summary of chromosomal composition in blastocysts yielded from CM and the co-culture system.

\begin{tabular}{|c|c|c|c|c|c|c|c|c|}
\hline \multirow[b]{2}{*}{ Culture } & \multirow{2}{*}{$\begin{array}{l}\text { No. blastocysts } \\
\text { analyzed }\end{array}$} & \multicolumn{6}{|c|}{ Blastocysts containing (\%): } & \multirow{2}{*}{$\begin{array}{c}\text { Total with } \\
\text { anomalies }(\%)\end{array}$} \\
\hline & & $2 n$ & $2 n / 3 n$ & $2 n / 4 n$ & $2 n / 3 n / 4 n$ & $4 n$ & Aneuploidy & \\
\hline Co-culture & $151 *$ & $\begin{array}{c}120 \\
(79.5)^{\mathrm{a}}\end{array}$ & $\begin{array}{c}7 \\
(4.6)\end{array}$ & $\begin{array}{r}12 \\
(7.9)\end{array}$ & $\begin{array}{c}2 \\
(1.3)\end{array}$ & $\begin{array}{c}3 \\
(2.0)\end{array}$ & $\begin{array}{c}2 \\
(1.3)\end{array}$ & $\begin{array}{c}31 \\
(20.9)^{\mathrm{c}}\end{array}$ \\
\hline $\mathrm{CM}^{* *}$ & 99 & $\begin{array}{c}62 \\
(62.6)^{\mathrm{c}}\end{array}$ & $\begin{array}{c}6 \\
(6.0)\end{array}$ & $\begin{array}{c}17 \\
(17.2)\end{array}$ & $\begin{array}{c}4 \\
(4.0)\end{array}$ & $\begin{array}{c}7 \\
(7.0)\end{array}$ & $\begin{array}{c}4 \\
(4.0)\end{array}$ & $\begin{array}{c}39 \\
(39.4)^{\mathrm{a}}\end{array}$ \\
\hline
\end{tabular}

*Data include CDM groups in Table 1. **Does not include SCM-CO and CO-SCM data.

a,c $P<0.001$.

this study. A majority of the mixoploid blastocysts were diploid-tetraploid, which is consistent with previous reports for NT embryos (Mohamed \& Takahashi 2000, Arat et al. 2002, Booth et al. 2003) and IVP embryos (Hare et al. 1980, Iwasaki et al. 1992, Mohamed \& Takahashi 2000). A haploid/diploid blastocyst was observed in the SCM-CO culture group. Mixoploidy of $1 \mathrm{n} / 2 \mathrm{n}$ is usually found in 2-cell (Slimane et al. 2000) and in 4- to 32-cell embryos (Iwasaki et al. 1992). It has been suggested that the $1 \mathrm{n} / 2 \mathrm{n}$ mosaic results from the retained activity of a polar body or is a product of polyspermy (King et al. 1981, Iwasaki et al. 1992). The mechanism that gives rise to a haploid NT blastocyst is unclear.

Chromosomal analysis of bovine embryos has indicated an overall incidence of abnormalities of $10 \%$ in in vivoderived embryos and $15-30 \%$ in IVP embryos (Kawarsky et al. 1996, Viuff et al. 2002). In another study, 20\% of in vivo bovine blastocysts and 44\% of IVP blastocysts had anomalies (Iwasaki et al. 1992). The rate of embryos with anomalies in whole blastocysts was significantly higher than in inner cell mass cells only, and most were 2n/4n (Iwasaki et al. 1992). In vivo, 2n/4n mixoploids have been observed in day $12-18$ bovine blastocysts (Hare et al. 1980). Results from diploid-tetraploid chimeras have confirmed that even high proportions of tetraploid cells are tolerated, but the tetraploid cells are eliminated in the developing embryo and are preferentially allocated to the extra-embryonic membranes (James et al. 1995). The fact that live-born calves do not usually exhibit chromosomal abnormalities suggests that embryos or fetuses with chromosomal anomalies are eliminated prenatally (King 1990, Kawarsky et al. 1996).

The formation of mixoploid embryos is assumed to result from cytokinetic failure, blastomere fusion, endoreduplication, or combinations of these events (King 1990). Tetraploid cells may arise through the fusion of two diploid blastomeres in a growing embryo (King et al. 1981) or from nuclear division without cytoplasmic division (Hare et al. 1980). Moreover, abnormalities imposed during in vitro culture of the embryo may cause abnormal chromosome segregation leading to mosaicism during cleavage, although Schumacher et al. (1998) concluded that physical factors associated with in vitro culture do not increase DNA ploidy abnormalities in rabbit embryos.

A high incidence of anomalies occurred in the CM groups in this study. The diploid complements were not improved even when a culture-change system was used. In a co-culture system, both the helper cell and the embryo contribute to a dynamic environment that results in increasing concentrations of growth factors and cytokines (Desai \& Goldfarb 1998). The rates of diploid blastocysts under co-culture versus non-co-culture conditions (cultured in CR1aa+3\% FCS, data not shown) were not different, but both were significantly higher than embryos in the $\mathrm{CM}$ group. The presence of serum in $\mathrm{CM}$, that is SCM, caused more anomalies than BCM (Table 4). Coincidently, both studies reported a high incidence of chromosomal abnormalities in bovine embryos (32-45\% in day 5 (Kawarsky et al. 1996), and $44 \%$ in days $6-8$ ) (Iwasaki et al. 1992) cultured in a co-culture system with 
cumulus cells (Iwasaki et al. 1992) or oviductal epithelial cells (Kawarsky et al. 1996) with medium TCM 199. A lower incidence of chromosomal anomalies was reported when cloned embryos were cultured in simple media (Mohamed \& Takahashi 2000, Arat et al. 2002). Because complex medium contains many components, as does serum, and particularly when the two are used together, it is difficult to identify factors that affect embryonic development and those factors that might alter the genetic composition of the embryo. It becomes even more complicated when a co-culture system is involved and more complex still when considering the potential effects of the NT procedure. All of these factors, particularly when used in an NT culture system, can affect chromosomal behavior and thus lead to chromosomal abnormalities.

The results of this study also showed that the rate of embryo development was significantly affected by the chromosomal complement. Embryos with chromosomal anomalies had decreased development, and cell number was significantly lower than diploid blastocysts in either $\mathrm{CM}$ or in co-culture (Tables 4 and 6). Morphologically poor blastocysts tended to have lower cell numbers and exhibited more chromosomal errors (King et al. 1987, Kawarsky et al. 1996).

In summary, CM has similar effects on the development of bovine NT embryos as the co-culture system. Cumulus cell CM may contribute to an increased incidence of blastocyst chromosomal abnormalities. In turn, chromosomal anomalies may lead to lower cloning efficiency and higher rates of embryonic, fetal, and perinatal mortality.

\section{Acknowledgement}

This work was supported by the Utah Agriculture Experiment Station (7556).

\section{References}

Arat S, Gibbons J, Rzucidleo SJ, Respess DS, Tumlin M \& Stice SL 2002 In vitro development of bovine nuclear transfer embryos from transgenic clonal lines of adult and fetal fibroblast cells of the same genotype. Biology of Reproduction 66 1768-1774.

Baranao RI, Piazza A, Rumi LS \& Polak de Fried E 1997 Determination of IL-1 and IL-6 levels in human embryo culture-conditioned media. American Journal of Reproductive Immunology 37 191-194.

Booth PJ, Viuff D, Tan S, Holm P, Greve T \& Callesen H 2003 Numerical chromosome errors in Day 7 somatic nuclear transfer bovine blastocysts. Biology of Reproduction 68 922-928.

Burgoyne PS, Holland K \& Stephens R 1991 Incidence of numerical chromosome anomalies in human pregnancy estimation from induced and spontaneous abortion data. Human Reproduction 6 $555-565$.

Desai N \& Goldfarb J 1998 Co-cultured human embryos may be subjected to widely different microenvironments: pattern of growth factor/cytokine release by Vero cells during the co-culture interval. Human Reproduction 13 1600-1605.

Funston RN, Nauta WJ \& Seidel GE Jr 1997 Culture of bovine embryos in buffalo rat liver cell-conditioned media or with leukemia inhibitory factor. Journal of Animal Science 75 1332-1336.
Galli C, Duchi R, Crotti G, Turini P, Ponderato N, Colleoni S, Lagutina I \& Lazzari G 2003 Bovine embryo technologies. Theriogenology 59 599-616.

Hare WCD, Singh EL, Betteridge KJ, Eaglesome MD, Randall GCB, Mitchell D, Bilton RJ \& Trounson AO 1980 Chromosomal analysis of 159 bovine embryos collected 12 to 18 days after estrus. Canadian Journal of Genetics and Cytology 22 615-626.

Hill JR 2002 Abnormal in utero development of cloned animals: implications for human cloning. Differentiation 69 174-178.

Ishiwata I, Tokieda Y, Kiguchi K, Sato K \& Ishikawa H 2000 Effects of embryotrophic factors on the embryogenesis and organogenesis of mouse embryos in vitro. Human Cell 13 185-195.

Iwasaki S, Hamano S, Kuwayama M, Yamashita $\mathbf{M}$, Ushijima $\mathbf{H}$, Nagaoka S \& Nakahara T 1992 Developmental changes in the incidence of chromosomes anomalies of bovine embryos fertilized in vitro. Journal of Experimental Zoology 261 79-85.

Izquierdo D, Villamediana P \& Paramio MT 1999 Effect of culture media on embryo development from prepubertal goat IVM-IVF oocytes. Theriogenology 52 847-861.

James RM, Klerkx AHEM, Keighren M, Flockhart JH \& West JD 1995 Restricted distribution of tetraploid cells in mouse tetraploiddiploid chimeras. Developmental Biology 167 213-226.

Joo BS, Kim MK, Na YJ, Moon HS, Lee KS \& Kim HD 2001 The mechanism of action of coculture on embryo development in the mouse model: direct embryo-to-cell contact and the removal of deleterious components. Fertility and Sterility 75 193-199.

Kawarsky SJ, Basrur PK, Stubbings RB, Hansen PJ \& King WA 1996 Chromosomal abnormalities in bovine embryos and their influence on development. Biology of Reproduction 54 53-59.

Keskintepe L, Burnley CA \& Brackett BG 1995 Production of viable bovine blastocysts in defined in vitro conditions. Biology of Reproduction 52 1410-1417.

King WA 1990 Chromosome abnormalities and pregnancy failure in domestic animals. Advanced Veterinary Science and Comprehensive Medicine 34 229-250.

King WA, Linares T \& Gustavsson I 1981 Cytogenetics of preimplantation embryos sired by bulls heterozygous for the $1 / 29$ translocation. Hereditas 94 219-224.

King WA, Guay P \& Picard L 1987 A cytogenetical study of 7-dayold bovine embryos of poor morphological quality. Genome 29 160-164.

Kobayashi K, Takagi Y, Satoh T, Hoshi H \& Oikawa T 1992 Development of early bovine embryos to the blastocyst stage in serum-free conditioned medium from bovine granulosa cells. In Vitro Cellular and Developmental Biology 28A 255-259.

Kobayashi M, Hirako M, Minato Y, Sasaki K, Horiuchi R \& Domeki I 1997 Rat hepatoma Reuber H-35 cells produce factors that promote the hatching of mouse embryos cultured in vitro. Biology of Reproduction 56 1041-1049.

Li GP, Cai SX, Xu LB \& Tan JH 1998 Studies on the early development of mouse tetraploid embryos produced by electrofusion. Development and Reproductive Biology 7 17-23.

Li GP, Seidel GE Jr \& Squires EL 2003 Intracytoplasmic sperm injection of bovine oocytes with stallion spermatozoa. Theriogenology 59 1143-1155.

Liu LP, Chan ST, Ho PC \& Yeung WS 1998 Partial purification of embryotrophic factors from human oviductal cells. Human Reproduction 13 1613-1619.

Mohamed NMS \& Takahashi Y 2000 In vitro developmental potential of bovine nuclear transfer embryos derived from primary cultured cumulus cells. Journal of Veterinary and Medicine Sciences 62 339-342.

Olson SE \& Seidel GE Jr 2000 Lowered oxygen tension and EDTA improve bovine zygote development in a chemically defined medium. Journal of Animal Science 78 152-157.

O'Neill C 1997 Evidence for the requirement of autocrine growth factors for development of mouse preimplantation embryos in vitro. Biology of Reproduction 56 229-237. 
Paria BC \& Dey SK 1990 Preimplantation embryo development in vitro: cooperative interactions among embryos and role of growth factors. PNAS 87 4756-4760.

Schumacher A, Kesdogan J \& Fischer B 1998 DNA ploidy abnormalities in rabbit preimplantation embryos are not increased by conditions associated with in vitro culture. Molecular Reproduction and Development 50 30-34.

Slimane W, Heyman Y, Lavergne Y, Humblot P \& Renard JP 2000 Assessing chromosomal abnormalities in two-cell bovine in vitro fertilized embryos by using in situ hybridization with three different cloned probes. Biology of Reproduction 62 628-635.

Slimane-Bureau W \& King WA 2002 Chromosomal abnormalities: a potential quality issue for cloned cattle embryos. Cloning and Stem Cells 4 319-329.

Slimane-Bureau W, Bordignon V, Leveillee C, Smith LC \& King WA 2003 Assesment of chromosomal abnormalities in bovine nuclear transfer embryos and in their donor cells. Cloning and Stem Cells 5 123-133.

Takahashi Y, Hishinuma M, Matsui M, Tanaka H \& Kanagawa H 1996 Development of in vitro matured/fertilized bovine embryos in a chemically defined medium: influence of oxygen concentration in the gas atmosphere. Journal of Veterinary and Medicine Sciences 58 897-902.
Van Langendoncket A, Vansteenbrugge A, Donnay I, Van Soom A, Berg U, Semple E, Grisart B, Mermillod P, Brem G, Massip A \& Dessy F 1996 Three year results of in vitro production of bovine embryos in serum-poor bovine oviduct conditioned medium. An overview. Reproduction, Nutrition, Development 36 493-502.

Vanroose G, Van Soon A \& de Kruif A 2001 From co-culture to defined medium: state of the art and practical considerations. Reproduction in Domestic Animals 36 25-28.

Viuff D, Palsgaard A, Rickords L, Lawson LG, Greve T, Schmidt M, Avery B, Hyttel P \& Thomsen PD 2002 Bovine embryos contain a higher proportion of polyploid cells in the trophectoderm than in the embryonic disc. Molecular Reproduction and Development 62 483-488.

Yin XJ, Tani T, Yonemura I, Kawakami M, Miyamoto K, Hasegawa R, Kato Y \& Tsunoda Y 2002 Production of cloned pigs from adult somatic cells by chemically assisted removal of maternal chromosomes. Biology of Reproduction 67 442-446.

Received 22 August 2003

First decision 8 October 2003

Accepted 28 October 2003 